\title{
ANALISIS FAKTOR RISIKO KELELAHAN KERJA PADA KARYAWAN BAGIAN PRODUKSI PT. ARWANA ANUGRAH KERAMIK, TbK
}

\author{
Mariani Juliana, Anita Camelia, Anita Rahmiwati \\ ${ }^{1}$ Fakultas Kesehatan Masyarakat Universitas Sriwijaya
RISK FACTORS ANALYSIS FOR FATIGUE IN PRODUCTION DEPARTEMENT EMPLOYEES OF PT. ARWANA ANUGRAH KERAMIK, Tbk

\begin{abstract}
Background: Work fatigue is one of the safety and health issues that can be a risk factor for accidents at work. Fatigue can be caused by several factors both internal and external factors. Internal factors included age, anemia status, length of service, sleep quality and workload, while external factors were work shift, and hot working climate. Meanwhile, the purpose of this research is to analyze the factors related to work fatigue in production employees of PT. Arwana Anugrah Keramik, Tbk.

Metode: This research use analytical research method with cross sectional approach. The population in this study was all employees who are in the production of PT Arwana Anugrah Ceramics, Tbk which amounted to 168 people. Sampling technique obtained sample of 75 people. Primary data collection using questionnaires and secondary data (study documentation). Data processing techniques using data analysis techniques are Chi-square.

Result: The result of the research showed that age ( $p$-value=0,793) and work period $(p$-value $=0,337)$ did not have significant correlation with work fatigue, while anemia status (p-value=0,012), work shift (pvalue $=0,021)$, sleep quality ( $p$-value=0,0001), workload $(p$-value $=0,001)$, and hot working climate $(p$ value $=0,004$ ) have a significant relationship with work fatigue.

Conclusion: The factors relating for fatigue in production departement employees of PT. Arwana Anugrah Keramik, Tbk is anemia status, work shift, sleep quality, workload, and hot working climate. To prevent work fatigue, the company PT Arwanan Anugrah Keramik, Tbk should provide transportation equipment to lighten the workload of employees, provide drinking water at a relatively affordable distance, and allow employees to take a break (10-15 minutes) every 1-2 hours.
\end{abstract}

Keyword: Work fatigue, risk factors, worker

\begin{abstract}
ABSTRAK
Latar Belakang: Kelelahan kerja adalah salah satu permasalahan kesehatan dan keselamatan kerja yang dapat menjadi faktor risiko terjadinya kecelakaan pada saat bekerja. Kelelahan dapat disebabkan oleh beberapa faktor baik faktor internal maupun faktor eksternal. Faktor internal diantaranya usia, status anemia, masa kerja, kualitas tidur, dan beban kerja, sedangkan faktor eksternal yaitu shift kerja dan iklim kerja panas. Adapun tujuan dari penelitian ini adalah untuk menganalisis faktor-faktor yang berhubungan dengan kelelahan kerja pada karyawan bagian produksi PT. Arwana Anugrah Keramik, Tbk.

Metode: Penelitian ini menggunakan metode analitik dengan pendekatan cross sectional. Populasi dalam penelitian ini adalah seluruh karyawan yang ada di bagian produksi PT. Arwana Anugrah Keramik, Tbk yang berjumlah 168 orang. Teknik sampling yang digunakan yaitu propability sampling dengan teknik simple random sampling diperoleh sampel sebesar 75 orang. Pengumpulan data primer menggunakan kuesioner dan data sekunder (studi dokumentasi). Teknik pengolahan data menggunakan teknik analisis data yaitu Chisquare.

Hasil Penelitian: Berdasarkan hasil penelitian yang dilakukan diperoleh bahwa usia $(p$-value $=0,793)$ dan masa kerja ( $p$-value $=0,337)$ tidak memiliki hubungan yang signifikan dengan kelelahan kerja, sedangkan status anemia ( $p$-value $=0,012)$, shift kerja $(p$-value $=0,021)$, kualitas tidur $(p$-value $=0,0001)$, beban kerja $(p$ value $=0,001)$, dan iklim kerja panas $(p$-value $=0,004)$ memiliki hubungan yang signifikan dengan kelelahan kerja.

Kesimpulan: Faktor yang berhubungan dengan kelelahan kerja pada karyawan bagian produksi PT. Arwana Anugrah Keramik, Tbk adalah status anemia, shift kerja, kualitas tidur, beban kerja, dan iklim kerja panas. Untuk mencegah kelelahan kerja, perusahaan PT. Arwana Anugrah Keramik, Tbk sebaiknya menyediakan alat angkut untuk meringankan beban kerja karyawan, menyediakan air minum pada jarak yang relatif terjangkau, serta memperbolehkan karyawan untuk beristirahat sejenak (10-15 menit) setiap 1-2 jam kerja.
\end{abstract}

Alamat Koresponding: Mariani Juliana, Fakultas Kesehatan Masyarakat Universitas Sriwijaya. Jl. Palembang Prabumulih KM. 32, Indralaya Indah Kabupaten Ogan Ilir, Sumatera Selatan, email : maria.liana34@yahoo.com 
Kata Kunci: Kelelahan kerja, faktor risiko, pekerja

\section{PENDAHULUAN}

Majunya perkembangan teknologi semakin mendorong Indonesia untuk mencapai tahap industrialisasi. Tertantangnya perusahaan untuk berproduksi selama 24 jam secara terus menerus merupakan konsekuensi dari perkembangan industri tersebut. Dengan demikian peningkatan kualitas serta kuantitas produksi sangat diharapkan untuk tercapainya keuntungan yang maksimal.

Menjalankan kegiatan produksi dan meningkatkan kualitas dan kuantitas produksi, diperlukan perlindungan terhadap tenaga kerja. Adapun perlindungan yang dimaksud adalah perlakuan yang sesuai martabat manusia, keselamatan, kesehatan, serta pemeliharaan moral kerja. Memberikan jaminan terhadap keselamatan dan meningkatkan derajat kesehatan tenaga kerja merupakan tujuan dari perlindungan tersebut. ${ }^{1}$

Salah satu permasalah K3 (Kesehatan dan Keselamatan Kerja) yang dapat menjadi pemicu terjadinya kecelakaan kerja adalah kelelahan. Kelelahan kerja merupakan suatu keadaan menurunnya efisiensi dan ketahanan seseorang dalam bekerja. ${ }^{1}$ Istilah kelelahan mengarah pada kondisi melemahnya tenaga kerja untuk melakukan suatu kegiatan, sehingga mengakibatkan terjadinya pengurangan kapasitas kerja dan ketahanan tubuh. $^{2}$

World Health Organization (WHO) meramalkan bahwa yang menjadi penyakit pembunuh nomor 2 setelah penyakit jantung adalah perasaan lelah yang berat. $^{3}$ Kementerian tenaga kerja Jepang melakukan penelitian terhadap 12 ribu perusahaan dan melibatkan sekitar 16 ribu orang tenaga kerja yang dipilih secara random, hasil dari penelitian tersebut menunjukkan bahwa $65 \%$ tenaga kerja mengeluhkan kelelahan fisik akibat kerja rutin, $28 \%$ mengeluhkan kelelahan mental dan sekitar $7 \%$ pekerja mengeluh stress berat dan merasa tersisihkan. Pada bagian produksi salah satu perusahaan di
Indonesia telah dilakukan penelitian, hasil penelitian menunjukkan bahwa gejala kelelahan yang dialami rata-rata pekerja adalah gejala sakit kepala, kaku di bahu serta nyeri punggung. ${ }^{4}$

Faktor penyebab kelelahan di industri sangat bervariasi. Lingkungan kerja dapat mempengaruhi kinerja pekerja, misalnya kebisingan, iklim kerja panas, pencahayaan yang buruk dan vibrasi dapat mengakibatkan ketidaknyamanan dalam bekerja. Apabila bekerja dengan kondisi tidak nyaman lama kelamaan akan menimbulkan kelelahan. ${ }^{5}$ Selain dari faktor fisik lingkungan kerja, Suma'mur memprediksi beberapa faktor utama yang signifikan terhadap kelelahan yang meliputi jenis kelamin, usia, status gizi, beban kerja, ukuran tubuh dari pekerja yang bersangkutan serta waktu yang digunakan dalam bekerja. ${ }^{6}$

Silaban menyebutkan faktor utama penyebab timbulnya kelelahan adalah pekerjaan bergilir. ${ }^{7}$ Secara alamiah, alam telah mengatur periodisasi waktu kerja dan istirahat. Pada siang hari dengan adanya matahari yang menyebabkan keadaan lingkungan menjadi terang membuat manusia mempunyai naluri untuk bekerja dan sebaliknya karena pengaruh gelap malam menimbulkan naluri manusia untuk beristirahat. Masa selama siang hari disebut fase ergotropik, yaitu kinerja manusia berada pada puncaknya, sementara masa malam hari disebut fase trophotropik, yaitu terjadinya proses istirahat dan pemulihan tenaga.

Tenaga kerja yang bekerja menggunakan sistem kerja begilir dan melakukannya dalam satu kali saja, maka circadian rhythms dapat kembali normal. Tetapi bila pekerja bekerja menggunakan sistem kerja bergilir secara terus menerus maka circadian rhythms tidak akan kembali normal. Dengan tidak kembalinya circadian rhythms maka dapat mengakibatkan gangguan tidur dan berbagai gejala lainnya. ${ }^{8}$ 
Penelitian ini akan dilakukan pada karyawan bagian produksi PT. Arwana Anugrah Keramik, Tbk yang merupakan perusahaan yang bergerak di bidang industri pembuatan keramik. Dari pengambilan data awal melalui survei lokasi diperoleh bahwa jumlah karyawan yang bekerja pada bagian produksi adalah 168 orang dan terbagi atas 3 shift kerja. Selain itu, proses produksi keramik juga melalui tahap pembakaran yang dapat mempengaruhi iklim kerja di bagian produksi. Iklim kerja panas dapat berpengaruh terhadap terjadinya kelelahan kerja. Adapun tujuan dari penelitian ini adalah untuk menganalisis faktor-faktor yang berhubungan dengan kelelahan kerja pada karyawan bagian produksi PT. Arwana Anugrah Keramik, Tbk.

\section{METODE}

Penelitian ini merupakan penelitian cross sectional dengan menggunakan metode kuantitatif. Populasi pada penelitian adalah seluruh karyawan bagian produksi PT. Arwana Anugrah Keramik, Tbk yang berjumlah 168 orang. Besarnya sampel pada penelitian ini berjumlah 75 orang, dan teknik pengambilan sampel yang digunakan dalam penelitian ini adalah teknik simple random sampling. Teknik ini merupakan pengambilan sampel sedemikian rupa sehingga setiap individu mendapat kesempatan yang sama untuk diambil sebagai sampel. ${ }^{9}$

Instrument yang digunakan dalam penelitian ini adalah sebagai berikut:

1. Indeks Suhu Bola Basah (ISBB) / Questemp $36^{\circ}$ digunakan untuk mengukur iklim kerja di lingkungan kerja.

2. Hb meter (Easy Touch GCHb Meter) digunakan untuk mengukur kadar hemoglobin karyawan.
3. Kuesioner digunakan untuk memperoleh data karyawan serta mencatat hasil pengukuran, yang terdiri dari:

a. Kuesioner 30 item gejala kelelahan kerja digunakan untuk mengukur tingkat kelelahan karyawan.

b. Kuesioner PSQI (Pittsburgh Sleep Quality Index) digunakan untuk mengukur kualitas tidur karyawan.

Analisis data terdiri dari analisis univariat untuk menggambarkan tiap-tiap variabel dan analisis bivariat menggunakan uji Chi-square dengan nilai signifikansi $95 \%$ atau $\alpha=0,05$ digunakan untuk melihat hubungan antara variabel independen terhadap variabel dependen. Data yang telah terolah kemudian disajikan dalam bentuk tabel dan teks dengan menggunakan kata-kata berupa narasi.

\section{HASIL PENELITIAN}

Tabel 1.

Distribusi Frekuensi Kelelahan Kerja pada Karyawan PT. Arwana Anugrah Keramik, Tbk

\begin{tabular}{ccc}
\hline Kelelahan Kerja & \multicolumn{2}{c}{ Total Responden } \\
\cline { 2 - 3 } & $\mathbf{n}$ & $\mathbf{\%}$ \\
\hline Tinggi & 11 & 14,7 \\
Sedang & 40 & 53,3 \\
Rendah & 24 & 32,0 \\
Jumlah & $\mathbf{7 5}$ & $\mathbf{1 0 0}$ \\
\hline
\end{tabular}

Data diatas menunjukkan bahwa tingkat kelelahan kerja yang dialami karyawan PT. Arwana Anugrah Keramik, Tbk cukup bervariasi. Berdasarkan tabel 1 dapat diketahui bahwa tingkat kelelahan kerja sedang merupakan tingkat kelelahan kerja yang paling banyak dialami karyawan yaitu sebanyak 40 orang $(53,3 \%)$. 
Tabel 2.

Distribusi Frekuensi Faktor Risiko Kelelahan Kerja pada PT. Arwana Anugrah Keramik, Tbk

\begin{tabular}{lcc}
\hline \multicolumn{1}{c}{ Variabel } & \multicolumn{2}{c}{ Total Responden } \\
\cline { 2 - 3 } & n & \% \\
\hline Usia & & \\
> 27 Tahun & 25 & 33,3 \\
<27 Tahun & 50 & 66,7 \\
Status Anemia & & \\
Anemia & 59 & 78,7 \\
Tidak Anemia & 16 & 21,3 \\
Masa Kerja & & \\
2 Tahun & 48 & 64 \\
<2 Tahun & 27 & 36 \\
Shift Kerja & & \\
Malam & 25 & 33,3 \\
Sore & 25 & 33,3 \\
Pagi & 25 & 33,3 \\
Kualitas Tidur & & \\
Buruk & 41 & 54,7 \\
Baik & 34 & 45,3 \\
Beban Kerja & & \\
Berat & 23 & 30,7 \\
Sedang & 45 & 60 \\
Ringan & 7 & 9,3 \\
Iklim Kerja Panas & & \\
Terpapar & 68 & 90,7 \\
Tidak Terpapar & 7 & 9,3 \\
\hline
\end{tabular}

Berdasarkan tabel 2 diperoleh informasi bahwa dari 75 orang total responden, mayoritas karyawan berusia $\leq 27$ tahun yaitu sebesar $66,7 \%$, yang mengalami anemia sebesar $78,7 \%$, dengan masa kerja $\geq 2$ tahun sebesar 64\%, shift kerja jumlahnya sama yaitu sebesar 33,3\%, kualitas tidur buruk sebesar $54,7 \%$, beban kerja dengan tingkat sedang sebesar $60 \%$, dan yang terpapar iklim kerja panas sebesar $90,7 \%$.

Tabel 3.

Hubungan Antara Usia, Status Anemia, Masa Kerja, Shift Kerja, Kualitas Tidur, Beban Kerja, dan Iklim Kerja Panas dengan Kelelahan Kerja

\begin{tabular}{|c|c|c|c|c|c|c|c|}
\hline \multirow[b]{2}{*}{ Variabel } & \multicolumn{4}{|c|}{ Kelelahan Kerja } & \multirow[b]{2}{*}{$\mathbf{n}$} & \multirow[b]{2}{*}{$p$-value } & \multirow[b]{2}{*}{ PR (95\%CI) } \\
\hline & $\begin{array}{c}\text { Tinggi } \\
\mathbf{n}\end{array}$ & $\%$ & $\begin{array}{c}\text { Rendah } \\
\text { n }\end{array}$ & $\%$ & & & \\
\hline \multicolumn{8}{|l|}{ Usia } \\
\hline$>27$ Tahun & 16 & 64 & 9 & 36 & 25 & 0,793 & $0,91(0,64-1,29)$ \\
\hline$\leq 27$ Tahun & 35 & 70 & 15 & 30 & 50 & & \\
\hline \multicolumn{8}{|l|}{ Status Anemia } \\
\hline Anemia & 43 & 76,8 & 13 & 23,2 & 56 & 0,012 & $1,82(1,05-3,15)$ \\
\hline Tidak Anemia & 8 & 42,1 & 11 & 57,9 & 19 & & \\
\hline \multicolumn{8}{|l|}{ Masa Kerja } \\
\hline$\geq 2$ Tahun & 35 & 72,9 & 13 & 27,1 & 48 & 0,337 & $1,23(0,86-1,75)$ \\
\hline$<2$ Tahun & 16 & 59,3 & 11 & 40,7 & 27 & & \\
\hline \multicolumn{8}{|l|}{ Shift Kerja } \\
\hline Malam & 22 & 88 & 3 & 12 & 25 & 0,014 & $\begin{array}{c}1,69 \\
(1,13-2,53)\end{array}$ \\
\hline Sore & 16 & 64 & 9 & 36 & 25 & 0,567 & $\begin{array}{c}1,23 \\
(0,76-1,98)\end{array}$ \\
\hline Pagi & 13 & 52 & 12 & 48 & 25 & & 1 \\
\hline Kualitas Tidur & & & & & & & \\
\hline Buruk & 37 & 90,2 & 4 & 9,8 & 41 & & \\
\hline
\end{tabular}




\begin{tabular}{lccccccc}
\hline $\begin{array}{l}\text { Baik } \\
\text { Beban Kerja }\end{array}$ & 14 & 41,2 & 20 & 58,8 & 34 & 0,0001 & $2,19(1,44-3,31)$ \\
$\begin{array}{l}\text { Berat } \\
\text { Sedang }\end{array}$ & 20 & 87 & 3 & 13 & 23 & 0,001 & $\begin{array}{c}6,08 \\
(0,98-37,62) \\
4,66\end{array}$ \\
& 30 & 66,7 & 15 & 33,3 & 45 & 0,013 & $(0,75-28,98)$ \\
$\begin{array}{l}\text { Ringan } \\
\text { Iklim Kerja Panas }\end{array}$ & 1 & 14,3 & 6 & 85,7 & 7 & & 1 \\
$\begin{array}{l}\text { Terpapar } \\
\text { Tidak Terpapar }\end{array}$ & 50 & 73,5 & 18 & 26,5 & 68 & & \\
\hline
\end{tabular}

Berdasarkan tabel 3 diatas, hasil analisis Chi-square menunjukkan bahwa status anemia, shift kerja, kualitas tidur, beban kerja, dan iklim kerja panas memiliki hubungan dengan kelelahan kerja pada karyawan bagian produksi PT. Arwana Anugrah Keramik, Tbk, sedangkan usia dan masa kerja tidak memiliki hubungan dengan kelelahan kerja.

\section{PEMBAHASAN \\ Kelelahan Kerja}

Kelelahan kerja menggambarkan seluruh respon tubuh terhadap aktivitas yang dilakukan dan paparan yang diterima selama bekerja. Ketika tubuh melakukan aktivitas selama bekerja 8 jam, tubuh akan rentan mengalami kelelahan. Tubuh yang mengalami kelelahan akan muncul gejala seperti sering menguap, haus, rasa mengantuk, dan susah berkonsentrasi. Ada tiga indikasi terjadinya kelelahan kerja yaitu pelemahan aktivitas, pelemahan motivasi kerja dan kelelahan fisik. Ketiga indikasi tersebut merupakan gejala yang dapat diamati untuk mengetahui kelelahan kerja.

Berdasarkan wawancara pengisian kuesioner diperoleh hasil yang menunjukkan bahwa mayoritas karyawan mengalami tingkat kelelahan kerja sedang yaitu sebesar 53,3\%, sedangkan tingkat kelelahan kerja rendah sebesar $32,0 \%$ dan tingkat kelelahan kerja tinggi sebesar $14,7 \%$. Penyebab kelelahan karyawan di bagian produksi PT. Arwana Anugrah Keramik, Tbk dapat berasal dari lingkungan pekerjaan yaitu iklim kerja panas. Selain itu, faktor individu seperti usia, status anemia, masa kerja, shift kerja, kualitas tidur, serta beban kerja juga dapat mempengaruhi tingkat kelelahan yang dialami oleh karyawan.

\section{Hubungan Usia dengan Kelelahan Kerja pada Karyawan PT. Arwana Anugrah Keramik, Tbk}

Usia adalah lamanya seseorang hidup mulai sejak lahir sampai ulang tahun terakhir pada saat penelitian berlangsung. Pengkategorian usia pada penelitian ini menggunakan nilai mean sebagai cut off point karena data yang diperoleh berdistribusi normal.

Berdasarkan hasil uji statistik Chisquare diperoleh nilai $p$-value $=0,793$, dapat diartikan bahwa tidak terdapat hubungan antara usia dengan kelelahan kerja. Hal ini dapat terjadi dikarenakan rata-rata usia karyawan dibawah 27 tahun, sehingga variasi data kelelahan pada kelompok tersebut juga tidak menunjukkan adanya perbedaan yang signifikan. Penelitian ini juga menunjukkan bahwa bukan hanya karyawan yang berusia tua yang mengalami kelelahan kerja tinggi, akan tetapi karyawan yang berusia muda juga dapat mengalami kelelahan kerja tinggi. Kelelahan tersebut bisa terjadi dikarenakan keadaan pekerjaaan yang monoton. Kondisi kerja yang berulang-ulang atau monoton, dapat menyebabkan rasa bosan, serta menjadikan karyawan merasa lelah dan jenuh. Namun dapat juga dikarenakan oleh beban kerja yang dirasakan karyawan, serta keadaan lingkungan seperti iklim kerja panas. Karyawan yang berusia tua juga tidak menutup kemungkinan mengalami kelelahan tingkat rendah karena pengalaman kerja yang 
dimiliki sehingga dapat menyiasati supaya tidak mengalami kelelahan tinggi.

Hasil penelitian ini sejalan dengan hasil penelitian yang dilakukan oleh Chesnal dengan menggunakan uji Chi-square didapatkan hasil bahwa tidak ada hubungan usia terhadap kelelahan kerja pada karyaawan bagian produksi PT. Putra Karangetang Popontolen Minahasa Selatan ( $p$ value $=0,807) .{ }^{10}$

\section{Hubungan Status Anemia dengan Kelelahan Kerja pada Karyawan PT. Arwana Anugrah Keramik, Tbk}

Kondisi rendahnya kadar hemoglobin darah seseorang disebut dengan anemia. Nilai batas normal anemia untuk pria dewasa adalah $\geq 13(\mathrm{gr} / \mathrm{L})^{2} .{ }^{11}$ Dalam fungsi transportasi $\mathrm{O}_{2}$, hemoglobin memiliki peranan penting. Saat melakukan aktivitas berat, kebutuhan energi akan meningkat berarti kebutuhan oleh jaringan juga meningkat. Aktivitas berat membuat jantung harus bekerja ekstra dengan meningkatkan volume dan frekuensi denyut jantung untuk memasok oksigen ke jaringan otot untuk melakukan aktivitas. ${ }^{12}$ Dengan kata lain, pengurangan kadar hemoglobin dalam darah sangat mempengaruhi ketahanan fisik dan produktivitas kerja seseorang. Menurunnya hemoglobin dalam darah dapat mengakibatkan metabolisme didalam otot terganggu dan terjadi penumpukan asam laktat yang menyebabkan rasa lelah. ${ }^{13}$

Berdasarkan analisis Chi-square diperoleh nilai $p$-value $=0,012$, dapat diartikan bahwa terdapat hubungan antara status anemia dengan kelelahan kerja pada karyawan bagian produksi PT. Arwana Anugrah Keramik, Tbk. Data yang diperoleh ketika penelitian menunjukkan bahwa sebanyak 56 orang karyawan PT. Arwana Anugrah Keramik, Tbk mengalami anemia. Tanda-tanda anemia yang sering dialami karyawan adalah mudah merasa lelah, kadang-kadang pusing, dan mudah mengantuk. Asupan gizi karyawan yang tidak sesuai dengan kebutuhan dan beban kerja serta jarangnya karyawan sarapan sebelum melakukan aktivitas juga menjadi pemicu terjadinya anemia.

Hal ini sejalan dengan penelitian Ramdan yang menyatakan bahwa status anemia berhubungan dengan kelelahan kerja (p-value $=0,0001) .{ }^{14}$ Hal ini kemungkinan dikarenakan faktor yang mempengaruhi kelelahan kerja bukanlah hanya faktor kadar hemoglobin, dalam perannya hemoglobin sebagai penyokong gizi untuk tubuh, karena fungsi hemoglobin yang salah satunya sebagai pengangkut zat gizi ke seluruh tubuh. ${ }^{15}$

\section{Hubungan Masa Kerja dengan Kelelahan Kerja pada Karyawan PT. Arwana Anugrah Keramik, Tbk}

Masa kerja adalah lamanya karyawan bekerja di PT. Arwana Anugrah Keramik, Tbk terhitung mulai pertama kali bekerja sampai pada saat penelitian ini dilakukan. Pengkategorian masa kerja pada penelitian ini menggunakan nilai mean sebagai cut off point karena data yang diperoleh berdistribusi normal. Berdasarkan hasil analisis Chi-square diperoleh nilai $p$-value $=0,337$, dapat diartikan bahwa tidak terdapat hubungan antara masa kerja dengan kelelahan kerja.

Masa kerja 2 tahun merupakan waktu yang cukup lama untuk pekerja beradaptasi dan menyesuaikan diri dengan aktivitas sehari-hari di tempat kerja. Namun pada penelitian ini karyawan yang memiliki masa kerja $\geq 2$ tahun lebih banyak mengalami kelelahan tinggi, hal ini kemungkinan dikarenakan adanya kecenderungan karyawan memiliki masa kerja $\geq 2$ tahun yaitu sebanyak 48 orang sedangkan karyawan yang memiliki masa kerja $<2$ tahun sebanyak 27 orang. Selain itu, adanya faktor lain yang mempengaruhi, seperti: monotoni kerja, lingkungan fisik kerja, dan faktor individu dapat menjadi pemicu terjadinya kelelahan.

Mauludi dalam penelitian yang dilakukannya pada tenaga kerja bagian produksi Kantong Semen PBD (Paper Bag 
Division) PT. Indocement Tunggal Perkasa, Tbk Citeurup-Bogor juga memperoleh hasil bahwa tidak terdapat hubungan masa kerja terhadap kelelahan kerja $(p$-value $=0,880){ }^{16}$

\section{Hubungan Shift Kerja dengan Kelelahan Kerja pada Karyawan PT. Arwana Anugrah Keramik, Tbk}

Setiap instansi pengguna sistem kerja bergilir perlu menyadari konsekuensi dari penerapan sistem tersebut, karena kondisi kerja antara siang hari dan malam hari sangat berbeda. Grandjean dalam Tarwaka, dkk, menyatakan bahwa secara alamiah alam telah mengatur periodisasi waktu kerja dan istirahat. Pada siang hari dengan adanya matahari yang menyebabkan keadaan lingkungan menjadi terang membuat manusia mempunyai naluri untuk bekerja dan sebaliknya karena pengaruh gelap malam menimbulkan naluri manusia untuk beristirahat. Masa selama siang hari disebut fase ergotropik, yaitu kinerja manusia berada pada puncaknya, sementara masa malam hari disebut fase trophotropik, yaitu terjadinya proses istirahat dan pemulihan tenaga. ${ }^{17}$ Karena keadaan tersebut, pekerja yang bekerja pada shift malam lebih mudah mengantuk dan lelah.

Berdasarkan hasil uji statistik Chisquare setelah dilakukan dummy variabel diperoleh nilai $p$-value $(1)=0,014$ yang berarti ada hubungan yang bermakna antara shift kerja malam terhadap kelelahan kerja dibandingkan dengan shift kerja pagi, dan $p$ value (2)=0,567 yang berarti tidak ada hubungan shift kerja sore terhadap kelelahan kerja. Adanya hubungan shift kerja malam terhadap kelelahan kerja pada penelitian ini dapat dilihat dari jumlah karyawan yang mengalami tingkat kelelahan tinggi lebih banyak pada shift kerja malam. Selain itu karyawan yang bekerja pada malam hari mengeluh merasa lelah dan mengantuk ketika bekerja disebabkan cuaca malam hari (angin malam), serta karyawan lebih memilih tidur daripada makan pada jam istirahat.

Menurut Suma'mur tenaga kerja yang bekerja pada malam hari akan mengalami tingkat kelelahan yang lebih besar dibandingkan tenaga kerja yang bekerja pada pagi hari atau siang hari, hal itu dikarenakan jumlah jam tidur/istirahat pada siang hari yang diperoleh tenaga kerja shift malam relatif jauh lebih kecil. ${ }^{6}$

Hal ini sejalan dengan penelitian sebelumnya yang dilakukan oleh Kimberly. Hasil penelitiannya menyatakan bahwa kelelahan kerja pada shift malam cenderung lebih tinggi. Hal tersebut dapat dilihat dari hasil pengukuran denyut nadi yang dilakukan. Denyut nadi tenaga kerja yang bekerja pada shift malam rata-rata lebih tinggi dibandingkan dengan yang bekerja pada shift pagi. ${ }^{18}$

\section{Hubungan Kualitas Tidur dengan Kelelahan Kerja pada Karyawan PT. Arwana Anugrah Keramik, Tbk}

Salah satu faktor yang berhubungan dengan penyebab terjadinya kelelahan adalah gangguan tidur yang antara lain dapat dipengaruhi oleh kurangnya waktu tidur dan gangguan pada jam biologis tubuh (circadian rhythms) akibat shift kerja.

Berdasarkan hasil uji statistic Chisquare diperoleh nilai $p$-value $=0,0001$, yang berarti terdapat hubungan antara kualitas tidur dengan kelelahan kerja pada karyawan bagian produksi PT. Arwana Anugrah Keramik, Tbk. Sebanyak 41 orang karyawan bagian produksi PT. Arwana Anugrah Keramik, Tbk memiliki kualitas tidur yang buruk.

Hal ini sesuai dengan teori Kroemer dan Grandjean yang menyatakan bahwa circadian rhythms merupakan salah satu faktor penyebab terjadinya kelelahan kerja di industri, yang apabila circadian rhythmsnya terganggu maka akan menyebabkan gangguan pola tidur pada seseorang dan dapat mempengaruhi kualitas tidurnya. ${ }^{19}$ Kualitas 
tidur yang buruk pada karyawan dapat dilihat dari lamanya karyawan tidur di malam hari rata-rata hanya 4-5 jam, masalah-masalah yang sering dirasakan yang mengganggu tidur mereka seperti tidak mampu tertidur selama 30 menit sejak berbaring, terbangun ditengah malam, terbangun untuk ke kamar mandi, kedinginan atau kepanasan di malam hari, dan ada juga yang menyebutkan alasan lain (seperti: anak rewel di malam hari).

Hasil penelitian ini sejalan dengan hasil penelitian Nanik bahwa ada hubungan yang signifikan antara kualitas tidur dengan terjadinya kelelahan kerja ( $p$-value $=0,043$ ). Gangguan tidur yang berhubungan dengan kelelahan biasanya disebabkan faktor-faktor seperti kebisingan, pencahayaan, kebiasaan minum yang berlebihan, dan faktor lainnya. ${ }^{20}$

\section{Hubungan Beban Kerja dengan Kelelahan Kerja pada Karyawan PT. Arwana Anugrah Keramik, Tbk}

Setiap pekerjaan akan menimbulkan beban kerja pada pekerja. Beban kerja yang dialami oleh karyawan PT. Arwana Anugrah Keramik, Tbk secara umum berbeda-beda dikarenakan perbedaan pekerjaan yang dilakukan. Pekerjaan karyawan dibagi berdasarkan lokasi kerja. Sebagai contoh, karyawan yang bekerja dibagian Sortir Packing bertugas memilah kualitas dan ukuran keramik, serta meyusun keramik kedalam pallet. Karyawan pada bagian sortir packing ini rata-rata mengalami beban kerja sedang. Beban kerja yang diterima karyawan diperoleh dari kondisi lingkungan kerja fisik, seperti: posisi kerja berdiri dan terkadang membungkuk serta uap panas keramik yang baru keluar dari kiln juga menyebabkan karyawan mudah merasa haus. Dibagian Glaze Prep, karyawan bertugas mengangkut bahan baku pembuatan keramik tanpa alat bantu. Beban kerja karyawan pada bagian ini lebih berat dibandingkan bagian lainnya dikarenakan membutuhkan energi yang lebih untuk mengangkut bahan baku.
Berdasarkan hasil uji statistik Chisquare setelah dilakukan dummy variabel diperoleh nilai $p$-value $(1)=0,001$ yang berarti terdapat hubungan yang signifikan antara beban kerja berat dengan kelelahan kerja dibandingkan dengan beban kerja ringan, dan $p$-value $(2)=0,013$ yang berarti terdapat hubungan antara beban kerja sedang dengan kelelahan kerja dibandingkan beban kerja ringan.

Tarwaka mengemukakan bahwa aktivitas kerja adalah penyebab timbulnya kelelahan. Adanya aktivitas kerja menyebabkan timbulnya beban kerja dari aktivitas yang dilakukan tersebut. ${ }^{21}$ Pekerjaan yang monoton akan mengakibatkan pembebanan otot secara statis. Suasana kerja dengan otot statis, aliran darah menurun, sehingga asam laktat terakumulasi dan mengakibatkan kelelahan otot lokal. ${ }^{22}$

Hasil penelitian ini sejalan dengan penelitian yang dilakukan oleh Irwandi, menyatakan bahwa ada hubungan antara beban kerja dan tugas tambahan. Banyaknya tugas tambahan yang dikerjakan oleh seseorang, akan menambah tinggi beban kerjanya. Apabila ini berlangsung terusmenerus maka akan mengakibatkan kelelahan kerja. $^{23}$

Adapun cara untuk mengendalikan kelelahan kerja yang diakibatkan beban kerja, sebaiknya pihak perusahaan memperhatikan kebutuhan karyawan, seperti meyediakan fasilitas air minum untuk mengurangi rasa haus karena iklim kerja panas, serta menyediakan alat bantu angkut.

\section{Hubungan Iklim Kerja Panas dengan Kelelahan Kerja pada Karyawan PT. Arwana Anugrah Keramik, Tbk}

Karyawan PT. Arwana Anugrah Keramik, Tbk melakukan pekerjaan di lima lokasi yang berbeda-beda iklim kerjanya. Berdasarkan hasil penelitian diketahui bahwa sebanyak 49 orang karyawan terpapar iklim kerja panas. Uji statistic Fisher's Exact 
menunjukkan bahwa nilai $p$-value $=0,004$, yang berarti terdapat hubungan yang bermakna antara iklim kerja panas dengan kelelahan kerja pada karyawan PT. Arwana Anugrah Keramik, Tbk.

Ada banyak penelitian yang menyimpulkan bahwa terdapat hubungan iklim kerja panas terhadap kelelahan kerja, diantaranya penelitian Ramdan yang dilakukan pada karyawan bagian produksi PT. LJP Provinsi Kalimantan Timur. Pada hasil penelitiannya, Ramdan menyatakan bahwa terdapat perbedaan perasaan kelelahan kerja yang signifikan antara tenaga kerja yang bekerja pada suhu di atas nilai ambang batas. $^{24}$

Suhu tubuh seseorang dapat meningkat diakibatkan oleh suhu lingkungannya yang tinggi. Ketika suhu tubuh seseorang meningkat, hipotalamus di dalam otak akan merangsang kelenjar keringat untuk mengeluarkan keringat. Pengeluaran keringat yang berlebihan akan menyebabkan tubuh kekurangan cairan serta mengurangi kadar ion natrium dan klorida dalam tubuh, yang dapat menghambat transportasi glukosa sebagai sumber energi dan pasokan darah ke organ tubuh. Hal ini menyebabkan penurunan kontraksi otot sehingga tubuh mengalami kelelahan. ${ }^{25}$

Seorang tenaga kerja akan bekerja dengan efisien dan produktif bila lingkungan tempat kerjanya nyaman, atau dapat dikatakan efisiensi kerja optimal dalam daerah nikmat kerja, tidak panas dan tidak dingin. Bagi orang Indonesia suhu nyaman ditempat kerja antara $21^{\circ} \mathrm{C}-30^{\circ} \mathrm{C}$ ISBB. ${ }^{26}$

Pada ruang produksi, dalam proses produksi keramik akan dilakukan tahap pembakaran menggunakan tungku pemanas (kiln) dengan suhu yang cukup lumayan tinggi guna mengubah massa yang rapuh menjadi massa yang padat, keras, dan kuat, sehingga iklim kerja di bagian produksi meningkat. Berdasarkan hasil pengukuran suhu dibagian produksi PT. Arwana Anugrah Keramik, Tbk diperoleh bahwa suhu tertinggi adalah $29,5^{\circ} \mathrm{C}$ dan suhu terendah $28,2^{\circ} \mathrm{C}$.

Perusahaan sudah mendesain ruang produksi dengan dinding terbuka pada semua sisi untuk mengurangi panas yang diakibatkan proses produksi keramik, serta ruang khusus untuk beristirahat (tempat istirahat dengan suhu $24-26^{\circ} \mathrm{C}$ ) yang terpisah dengan proses kerja untuk pemulihan tenaga, namun pihak perusahaan belum menyediakan waktu atau mengizinkan karyawan untuk beristirahat sejenak (sekitar 5-15 menit) setiap 1-2 jam kerja serta belum menyediakan fasilitas air minum untuk karyawan dengan jarak yang relative dekat dari semua area tempat kerja. Hal-hal tersebut sebaiknya diperhatikan oleh pihak perusahaan karena dapat menghindari/mengurangi terjadinya kelelahan kerja pada karyawan.

\section{KESIMPULAN DAN SARAN}

Gambaran kelelahan kerja pada karyawan PT. Arwana Anugrah Keramik, Tbk dengan kategori sedang $(53,3 \%)$, karyawan yang berusia $\leq 27$ tahun $(66,7 \%)$, karyawan dengan status anemia $(78,8 \%)$, karyawan dengan masa kerja $\geq 2$ tahun (64\%), karyawan dengan kualitas tidur buruk $(54,7 \%)$, beban kerja yang dialami karyawan dalam kategori sedang (60\%) dan karyawan yang terpapar iklim kerja panas $(90,7 \%)$. Berdasarkan analisis bivariat tidak terdapat hubungan antara usia dan masa kerja dengan kelelahan kerja pada karyawan PT. Arwana Anugrah Keramik, Tbk. Terdapat hubungan antara status anemia, shift kerja, kualitas tidur, beban kerja, dan iklim kerja panas dengan kelelahan kerja pada karyawan PT. Arwana Anugrah Keramik, Tbk.

Saran dari penelitian ini adalah sebagai berikut:

1. Pihak perusahaan disarankan sebaiknya menyediakan alat bantu angkut seperti crane untuk mengangkut bahan baku keramik untuk menghindari kelelahan 
kerja yang diakibatkan oleh beban kerja yang berlebihan.

2. Pihak perusahaan disarankan sebaiknya menginformasikan kepada karyawan untuk minum sebanyak 150-200 ml setiap 15-20 menit serta menyediakan fasilitas air minum untuk karyawan dengan jarak yang relatif dekat dari semua area tempat kerja untuk menghindari adanya dehidrasi dikarenakan iklim kerja panas.

3. Pihak perusahaan disarankan sebaiknya memperhatikan gizi pekerja, seperti

\section{DAFTAR PUSTAKA}

1. Suma'mur, P. K. Higiene Perusahaan dan Kesehatan Kerja (HIPERKES). Jakarta: Sagung Seto. 2009.

2. Nurmianto, E. Ergonomi Konsep Dasar dan Aplikasinya. Surabaya: Guna Widya. 2003.

3. World Health Organization (WHO). Globals Goals for Oral Health 2020. 2003. Online: http://www.who.int/oralhealth/publicatio ns/goals2020/en/.

4. Miranti, S.W. Caecillia, dan Yuniar. Tingkat Beban Kerja Mental Masinis Berdasarkan NASA - TLX (Task Load Index) di PT. KAI Daop II Bandung. Jurnal Online Institut Teknologi Nasional. 2008. Vol.01. No.1.

5. Setyawati. Kelelahan Kerja dan Stress Kerja. Jurnal Proceeding Seminar Ergonomi, Aplikasi Ergonomi dalam Industri. Forum Komunikasi Teknik Industri Yogyakarta dan Perhimpunan Ergonomi Indonesia. Yogyakarta. 2006.

6. Suma'mur, PK. Higiene Perusahaan dan Kesehatan Kerja. Jakarta: Gunung Agung. 1996.

7. Silaban, G. Kelelahan Kerja. Majalah Kesehatan Masyarakat Indonesia (MKMI) Tahun XXVI. 1998. Vol.10, pp. $539-544$.

8. Dekker, D.K., Tepas, D.I., dan Colligan, M.J. The Human Faktors Aspect of Shiftwork. Occupational Ergonomics Theory and Applications. Marcel Dekker. Inc. New York. 1996. memberikan asupan gizi yang sesuai dengan beban kerja karyawan terutama karyawan yang bekerja pada malam hari.

4. Karyawan diharapkan dapat mengenali gejala timbulnya kelelahan dan pihak perusahaan disarankan sebaiknya memberikan izin kepada karyawan untuk beristirahat setiap 1-2 jam kerja selama 515 menit untuk menghindari kejadian yang tidak diinginkan.

9. Budiarto, Eko, Dr. Biostatistika untuk Kedokteran dan Kesehatan Masyarakat. Jakarta: EGC. 2002.

10. Chesnal, H. Hubungan Antara Umur, Jenis Kelamin, dan Status Gizi dengan Kelelahan Kerja pada Tenaga Kerja di Bagian Produksi PT. Putra Karangetang Popontolen Minahasa Selatan. Artikel Penelitian Kesehatan Masyarakat Universitas Sam Ratulangi Manado. 2014.

11. Arisman. Gizi dalam Daur Kehidupan. Jakarta: ECG. 2009.

12. Baldy, C. M. 2001. Sel Darah Merah dalam Patofisiologi Konsep Klinis Proses-Proses Penyakit. Jakarta: EGC.

13. Almatsier, S. Prinsip Dasar Ilmu Gizi. Jakarta: PT Gramedia Pustaka Utama. 2003.

14. Ramdan, I. M. Faktor-Faktor yang Berhubungan dengan Kelelahan Kerja pada Tenaga Kerja Wanita di PT. RRL Kalimantan Timur Tahun 2014. Makalah Seminar Nasional Global Health 2014 Fakultas Kesehatan Masyarakat Universitas Mulawarman. 2014.

15. Suma'mur. Ergonomi untuk Produktivitas. Jakarta: CV. Haji Mas Agung. 2003.

16. Mauludi, M. N. Faktor-Faktor yang Berhubungan dengan Kelelahan pada Pekerja di Proses Produksi Kantong Semen PBD (Paper Bag Division) PT. Indocement Tunggal Prakarsa, Tbk Citeureup-Bogor Tahun 2010. [Skripsi]. Universitas Islam Negeri Syarif Hidayatullah. 2010. 
17. Tarwaka, Bakri, HA. Solichul, dan Sudiajeng, L. Ergonomi untuk Keselamatan dan Kesehatan Kerja dan Produktivitas. Surakarta: UNIPRESS. 2004.

18. Kimberly. Pengaruh Shift Kerja terhadap Kelelahan Pekerja Pabrik Kelapa Sawit di PT. X Labuhan Batu. Jurnal Teknik Industri. 2011. Vol.12, No.2, pp.110-117.

19. Kroemer, K. H. E dan Grandjean, E. Fitting The Task To The Human. A. Textbook Of Occupational Ergonomics. $5^{\text {th }}$ Edition. London and New York: Taylor \& Francis. 2005.

20. Nanik. Hubungan Antara Karakteristik Individu, Sikap Kerja dan Kualitas Tidur dengan Kelelahan Kerja pada Perawat RS. X Gresik. 2008.

21. Tarwaka. Dasar-Dasar Pengetauan Ergonomic dan Aplikasi di Tempat Kerja. Solo: Harapan Press Solo. 2010.

22. Nurmianto, E. Ergonomi Konsep Dasar dan Aplikasinya. Edisi Ke - 2. Surabaya: Guna Widya. 2008.
23. Irwandi. Faktor-Faktor yang Berhubungan dengan Beban Kerja Perawat Pelaksana di Unit Rawat Inap Rumah Sakit Jiwa Pusat Makassar Tahun 2005. [Skripsi]: Fakultas Kesehatan Masyarakat Universitas Hasanuddin Makassar. 2006.

24. Ramdan, I. M. Dampak Giliran Kerja, Suhu dan Kebisingan terhadap Perasaan Kelelahan Kerja di PT. LJP Provinsi Kalimantan Timur. The Indonesian Journal of Public Health. 2007. Vol.4, No.1, pp.13.

25. Guyton, AC dan Hall John E. Buku Ajar Fisiologi Kedokteran. Setiawan I, Tengadi KA, Santoso A, penerjemah: Setiawan I, editor. Jakarta: EGC. Terjemah dari: Textbook of Medical Physiology. 1991.

26. Suma'mur, P. K. Higiene Perusahaan dan Kesehatan Kerja (HIPERKES). Jakarta: Sagung Seto. 1991. 